\section{MEETINGS AND COURSES}

\section{THIS MONTH}

\section{October 26th 2001}

Title. Staying young - new issues in women's health for primary care. Venue. Tuke Hall, Regent's College, Regent's Park, London. Details. A course for general practitioners, suitable for your personal development plans. Covers: osteoporosis, perimenopause, alternative treatments for older women - doing more harm?, sexuality and the older woman. Fee $£ 120$. Accreditation. PGEA and FFP approved. Information. Heather Goodman, Margaret Pyke Centre, 73 Charlotte Street, London W1T 4PL. Tel: 0207436 8390, Fax: 0207580 2495, Email: mpmttraining@ hotmail.com

\section{Academic year 2001/2002}

Title. Courses in sexual and reproductive health. Details. A complete range of multidisciplinary courses from free-standing postgraduate awards in individual subject areas to a full MSc in community gynaecology and reproductive health care. Details. Mrs Sharon West, School of Postgraduate Medical Education, Westwood, University of Warwick, Coventry, CU4 7AL Tel: 0247652 2913, Fax: 0247652 4311, Email: s.c.west@warwick.ac.uk

\section{NOVEMBER}

\section{November 7th-9th 2001}

Title. Residential instructing doctors course. Venue. Haven Hotel, Sandbanks, Poole, Dorset. Details. $£ 525$ to include accommodation, full board, tuition fees and leisure facilities. Accreditation. PGEA and FFP approved. Information. Heather Goodman, Margaret Pyke Centre, 73 Charlotte Street, London W1T 4PL. Tel: 0207436 8390, Fax: 0207580 2495, Email: mpmttraining@ hotmail.com

\section{November 13th 2001}

Title. Training the trainers. Venue. Trafford Postgraduate Education Centre, Manchester Details. Suitable for FP doctors updating Accreditation. Suitable for CME/RCOG. PGEA and FFP applied for. Information. Ann Conti, Regional Training Office, 63-65 Palatine Rd, Manchester, M20 3LJ. Tel: 0161434 8629, Fax: 01614481889 .

\section{November 17th and 18th 2001}

Title. Weekend family planning theory course for doctors. Venue. Northwick Park Hospital,
Harrow, Middlesex. Details. Theoretical component for the DFFP suitable for continuing professional development. Accreditation. Faculty recertification and RCOG CME Faculty and PGEA approvals applied for. Information. Diane Price, Family Planning Training Office, Level 6, Maternity Block, Northwick Park Hospital, Watford Road, Harrow, HA1 3UJ. Tel: 0208869 3127, Fax: 02088692903.

\section{DECEMBER}

\section{December 5th 2001}

Title. Half-day menopause course. Venue. Chancellors, Mosley Road, Fallowfield, Manchester. Details. Suitable for GPs and practice nurses to update on menopause. Accreditation. Suitable for CME. PGEA, FFP, RCN applied for. Information. Irene Healey, Regional Training Office, 63 Palatine Road, Manchester, M20 3LJ. Tel: 0161434 8629, Fax: 01614481889.

\section{December 13th and 14th}

Title. Basic course for the Faculty of Family Planning and Reproductive Health Care. Venue Institute for Child Health, 30 Guilford Street, London WC1N 1GH. Details. Organised by John Guillebaud, Professor of Family Planning and Reproductive Health. Accreditation. First part of DFFP and PGEA. Information. Dawn Atkinson, Margaret Pyke Centre, 73 Charlotte Street, London, W1T 4PL. Tel: 02075303608 , Fax: 02075303646.

\section{December 14th 2001}

Title. Sexual health, the older woman and HRT. Venue. Regent's College, Regent's Park, London NW1. Details. See full page advert (page XXX). Information. Information. Heather Goodman, Margaret Pyke Centre, 73 Charlotte Street, London W1T 4PL. Tel: 0207436 8390, Fax: 020 7580 2495, Email: mpmttraining @ hotmail.com

\section{JANUARY}

\section{January 15th and 16th 2002}

Title. DFFP basic theory course. Venue. Trafford Postgraduate Education Centre, Manchester. Details. Suitable for FP doctors updating. Accreditation. Suitable for CME/RCOG. PGEA and FFP applied for. Information. Ann Conti, Regional Training Office, 63-65 Palatine Road, Manchester, M20 3LJ. Tel: 0161434 8629, Fax: 01614481889 .

\section{January 16th-18th 2002}

Title. Diploma in family planning. Venue.
Medical Education Centre, Chesterfield Royal Hospital NHS Trust. Details. Three-day theoretical course for the diploma of the Faculty of Family Planning and Reproductive Health Care and updating for those interested in reproductive health care. Accreditation. PGEA and Section 63 applied for. Information. Val Johnson, Education Centre Manager, Chesterfield Royal Hospital NHS Trust, Chesterfield, Derbyshire S44 5BL. Tel: 01246 552057, Fax: 01246552685.

\section{FEBRUARY}

\section{February 22nd-24th 2002}

Title. Potential instructing doctors course. Venue. Cottons Hotel, Knutsford, Cheshire. Details. Two and a half-day residential course for doctors wishing to obtain the Letter of Competence for Faculty Instructing Doctors (Loc FIN Doc). Accreditation. Suitable for CME/RCOG. PGEA and FFP applied for. Information. Ann Conti, Regional Training Office, 63-65 Palatine Road, Manchester, M20 3LJ. Tel: 0161434 8629, Fax: 01614481889 .

\section{February 23rd-28th 2002}

Title. Second International. Venue. Bangkok, Thailand. Details. A stimulating multidisciplinary conference on practical sexual health care for those working in the field. Covering HIV/STIs, sexual health promotion/ prevention and networking, and adolescent sexual health. Not to be missed! Accreditation. $\mathrm{RCP}$, RCOG, DFFP, PGEA. Information. Dr Richard Burack, 12 Heathfield Park Drive, Chadwell Heath, Essex RN16 4FB, UK. Tel: 020 8599 8029, Fax: 0208599 8029, Email: siamcare@aol.com

There is a charge of $£ 50+$ VAT for each meeting/course publicised in the Meetings and Courses column of the Journal. This will guarantee inclusion in the issue requested. For further information please contact Sarah Monger at PMH Publications, PO Box 100, Chichester, West Sussex, PO18 8HD, UK. Tel: +44 (0)1243 576444; Fax: +44 (0)1243 576456; Email:adsales@ @mh.uk.com. 